International Business and Global Economy 2018, no. 37, pp. 312-322

Biznes międzynarodowy w gospodarce globalnej 2018, nr 37, s. 312-322

Edited by the Institute of International Business, University of Gdańsk

ISSN 2300-6102

e-ISSN 2353-9496

DOI 10.4467/23539496IB.18.022.9395

Joanna Pietrzak

Uniwersytet Gdański

\title{
Country-specific factors of accumulating private wealth - evidence from international students' essays
}

The aim of the paper is to identify the differences in international students' perception of sources of private wealth resulting from their country-specific experience. In particular, it was interesting to see whether there would be significant differences in the opinions of students representing wellestablished economies and those from post-socialist or transition economies. The results of this study are based on the qualitative directed content analysis of 106 essays titled What are the main private wealth drivers in your country? written by students from Poland, Austria, Russia, the Netherlands, Germany, Sweden, and Ukraine. The most significant discrepancies referred to the role of inheritance and the importance of labour income in the process of private wealth accumulation. Inheritance was indicated as a strong wealth driver by all students from developed economies while being almost totally ignored by others. The significance of income from employment was also seen differently by the two groups. Country-specific opinions referred to private business areas and the way business should be conducted. Insightful impact was brought by numerous critical observations of local market dysfunctions, expressed spontaneously by students from post-socialist countries.

Keywords: wealth, income, capital, sources of private wealth

JEL classification: B5, E22, J30, P34

\section{Czynniki akumulacji prywatnego majątku w opinii studentów międzynarodowych}

Celem tego artykułu jest identyfikacja różnic w postrzeganiu mechanizmów gromadzenia prywatnego bogactwa przez studentów z krajów rozwiniętych i krajów post-socjalistycznych. Wyniki zaprezentowano w oparciu o jakościową analizę treści 106 esejów napisanych przez studentów z Polski, Austrii, Rosji, Holandii, Niemiec, Szwecji i Ukrainy. Pod uwagę wzięto następujące czynniki: dziedziczenie, dochody z prywatnej przedsiębiorczości, dochody z pracy, dochody z kapitału finansowego i materialnego, inne źródła dochodów. Najbardziej wyraźne różnice ujawniły się w postrzeganiu rangi dwóch czynników: dziedziczenia oraz dochodów z pracy najemnej. Pierwszy czynnik, podkreślany jako kluczowy przez studentów z krajów rozwiniętych, był z reguły pomijany przez studentów z krajów post-socjalistycznych, którzy z kolei przykładali dużą wagę do stałych zarobków z pracy najemnej. Różnice wynikające z doświadczeń lokalnych dotyczyły również znajomości rynków finansowych oraz dziedzin, w których warto rozwijać własny biznes. Ważnym elementem poznawczym były spontaniczne komentarze krytyczne dotyczące dysfunkcji w mechanizmach bogacenia się w Polsce, Rosji i Ukrainie.

Słowa kluczowe: majątek, dochody, kapitał, źródła prywatnego majątku

Klasyfikacja JEL: B5, E22, J30, P34 


\section{Introduction}

During the last decade, a rapid accumulation of private wealth has been observed in most countries of the world. This phenomenon is supposed to accelerate in the coming years to $6 \%$ globally (a growth rate far exceeding that of global GDP) to reach over USD 220 tn held by private individuals by 2021 [Consultancy.uk, 2017]. One of the most interesting topics in this area is the identification of factors that have the biggest impact on the process of private wealth accumulation. There is a wide collection of articles and books addressing this problem and providing us with relevant knowledge about the most powerful wealth drivers. Therefore, the research question put up in the present study is, to what extent this extensively accessible knowledge is reflected in international students' minds and how their individual experience and observation of local market conditions influences their opinion on the mechanisms of wealth accumulation.

The aim of the paper is to identify country-specific differences in the perception of sources of wealth by international students resulting from their experience based on different economic conditions they live in. In particular, it was interesting to see if the order of importance attributed to particular wealth drivers would differ among students from established and less developed economies. For this purpose, the results of my teaching experience were used in the form of the analysis of 106 essays written by international students on the subject of main private wealth creation factors observed in their countries. The results of the study revealed significant differences in the order of priority given to particular wealth drivers, depending on the state of economic development of students' native countries. Numerous examples of country-specific ways of making money, highlighted as meaningful by one group of students, were not mentioned at all by their peers from other countries. Most interesting, however, were the spontaneous remarks made by students from Poland, Russia, and Ukraine, pointing to numerous dysfunctions and abnormalities of the economic system in their countries.

\section{Sources of private wealth - literature review}

The most influential book discussing the consequences of the increasing amount of private wealth was Galbraith's The affluent society [1958]. Galbraith played a pioneering role in pointing out that conventional economic thinking was no longer suited to the unprecedented phenomenon of mass affluence achieved by the American society in the $20^{\text {th }}$ century. At present, the discussion tends to concentrate on wealth inequalities and the sources of private wealth. Many authors point to traditional factors such as land and capital ownership as the key contribu- 
tors to private and national wealth [O'Driscoll, Hoskins, 2003]. According to Smith [2015], it is the landowners and homeowners in particular, who are grabbing the largest share of wealth growth. A similar way of thinking is reflected in Linklater's book Owning the Earth: The transforming history of land ownership [2013]. The author emphasizes the fact that the ideas of private property merged seamlessly from an agrarian to an industrial society. The structure of landowner-tenant-labourer was translated into that of shareholder-manager-worker. The pattern also works in post-industrial society, since the ideas behind the common law of property could easily encompass intellectual property. The two essential elements of property rights are (1) the exclusive right of individuals to use their resources as long as they do not violate someone else's rights and (2) the ability of individuals to transfer or exchange those rights on a voluntary basis. In the case of intellectual property, it gives the owner the right to exclude others from exploiting assets restricted by patents, copyrights, and other intellectual property rights. In consequence, a significant amount of money is being redistributed from the bulk of the population to those in a position to benefit from owning intellectual property.

The role of capital as a powerful wealth driver is highlighted by Piketty in his book Capital in the twenty-first century [2014]. He argues that one of the key reasons underlying the huge concentration of wealth in the hands of privileged groups is increasing return to capital versus labour. In almost all countries, both developed and developing, the share of national income going to workers has been falling down. Workers are capturing less and less of the gains from growth. In contrast, the owners of capital have seen their capital consistently grow through interest payments, dividends, or retained profits. Furthermore, the direction of technological change favours capital over labour and, within labour, skilled labour over unskilled one. The problem of substituting traditional factors of industrial production - land, labour, and capital, with more and more technologically advanced knowledge was raised by Tofler and Tofler in their Revolutionary wealth [2007].

Although the age of aristocrats seems to be over, recent studies bring substantial evidence of the growing importance of inheritances among factors influencing social position of a household in a wealth pyramid. According to the ECB study "Private wealth across European countries: The role of income, inheritance and the welfare state" [Fessler, Schurz, 2015], inheritance plays a decisive role in defining the relative position of households in the distribution of wealth across all euro area countries. Research results presented in the study indicate that on average, an intergenerational transfer lifts a household by 14 net wealth percentiles, while an additional percentile in the income distribution is associated with 0.4 net wealth percentiles ${ }^{1}$. Receiving an intergenerational transfer is therefore a higher contributor to net wealth, being equivalent to an income increase that leads to

\footnotetext{
1 Net wealth is defined here as real assets plus financial assets minus debt.
} 
a new rank in the income distribution about 35 percentiles higher. Heir households hold substantially higher net wealth levels than their non-heir counterparts. At this point it is worth noting that wealth is often misinterpreted or equated with income; the two concepts should therefore be clarified. Income represents the flow of cash that a household earns every year, whereas wealth is the total stock of assets that a household owns, either through accumulation or inheritance. The difference between wealth and income has been highlighted by Kennickell in his symbolic metaphor of "ponds and streams" [2008]. Whereas income streams take mostly the form of cash, the wealth components are much more numerous and include both financial and non-financial assets. Wealth is also an important metric since it can be inherited, unlike income.

Income is the next key contributor to private wealth, although, according to Piketty, it loses importance as the critical source of wealth over time. Since income streams may come from different sources, they can further be divided into three separate categories: (1) labour income from employment or self-employment; (2) income from financial wealth such as interest and dividends; and (3) income from real wealth such as rental income. It should be mentioned, however, that the last two categories (income from financial wealth or real wealth) require investments and are only available to individuals and households at the top of wealth distribution. To make the picture complete, one may take into consideration also the streams of income coming from welfare state benefits. Thus, gross household income can be presented as the sum of employee income, self-employment income, income from real estate property, income from financial investments, income from private business and partnerships, income from pensions, regular social and private transfers, and other non-specified sources of income [Fessler, Schurz, 2015]. The last category is very versatile and may include sources that are common to all wealth markets, as well as those drivers that are region specific [Maude, 2006].

Taking all mentioned views into consideration, the process of building private wealth may be presented as follows: inheritance increases the total stock of assets, income streams intensify the ability to accumulate assets, and economic and policy changes - including globalization, deregulation, and privatization - contribute to further concentration of private wealth.

\section{Research methodology}

The present study is based on the analysis of 106 essays written by international students during the courses taught by me in 2014-2016: "Private Banking \& Wealth Management" taught at Vorarlberg University of Applied Science in 
Dornbirn (Austria) and "Marketing in the Financial Sector" taught at the University of Gdańsk (Poland). All essays had the same title: What are the main private wealth drivers in your country? and were written by students representing the following countries: Poland (35 essays), Austria (22), Russia (15), the Netherlands (14), Germany (8), Sweden (8), and Ukraine (4). Such composition made it possible to compare essays written by students from developed economies (Austria, Germany, the Netherlands, Sweden) with those from developing or transition economies (Poland, Russia, Ukraine).

Given a wide set of non-numerical data reflecting the points of views of the targeted population (students), a qualitative research method has been applied. Qualitative research is primarily exploratory and it is used to gain an understanding of underlying reasons, opinions, and motivations [Crossman, 2016]. Out of many qualitative research techniques, the content analysis has been used as a "a research method for the subjective interpretation of the content of text data through the systematic classification process of coding and identifying themes or patterns" [Hsieh, Shannon, 2005, p. 1278]. This approach allows to throw a light on the influence of economic and social conditions on the international students' understanding of wealth accumulation factors in their countries. The research process was organized according to the following phases.

Table 1. Phases of thematic analysis

\begin{tabular}{|l|l|}
\hline \multicolumn{1}{|c|}{ Phase } & \multicolumn{1}{c|}{ Description } \\
\hline $\begin{array}{l}\text { familiarising myself } \\
\text { with data }\end{array}$ & transcribing data from the essays \\
\hline generating initial codes & $\begin{array}{l}\text { coding interesting features of the data in a systematic way across entire } \\
\text { data set; collating data relevant to each code }\end{array}$ \\
\hline searching for themes & collating codes into potential themes \\
\hline $\begin{array}{l}\text { reviewing, defining, } \\
\text { and naming themes }\end{array}$ & $\begin{array}{l}\text { checking if themes work in relation to the coded extracts across the } \\
\text { entire data set; generating clear definitions and names for each theme }\end{array}$ \\
\hline producing the report & $\begin{array}{l}\text { selection of vivid, compelling extract examples; final analysis of selec- } \\
\text { ted extracts; relating the analysis back to the research question, objec- } \\
\text { tives and literature reviewed }\end{array}$ \\
\hline
\end{tabular}

Source: Own elaboration based on: [Braun, Clarke, 2006].

Out of three possible approaches to qualitative content analysis: conventional, directed, and summative [Hsieh, Shannon, 2005], a directed content analysis has been applied, in which initial coding starts with a theory or relevant research findings. Since in the case of wealth accumulation there is no single theory on which the study could be based, an extensive literature review has been taken as a ground to a proper coding scheme. Categories have been derived from previous related studies and the data gathered from students' essays. In that way the 
strongest contributors to private net wealth have been identified and put in the descending order according to their relative influence on wealth building process: inheritance, income from private business, income from financial investments, income from real estate property, income from employment and self-employment, and other non-specified sources of income. The next stage of research consisted in verifying whether and how these categories were reflected in students' essays and whether there were any country-specific features attributed to them.

\section{Research results}

Factors identified as the main contributors to private wealth were analysed with the view to finding any significant differences in students' perception. Whenever some original statements appeared, they were cited and confronted with other corresponding statements. The results are presented below, according to the sequence of categories contributing to private wealth.

\subsection{Inheritance}

This factor revealed significant differences concerning the evaluation of its importance by students from developed and transforming economies. First, inheritance was mentioned as a meaningful source of wealth in all Western students' essays. Additionally, in essays from Austria, Germany, and Sweden inheritance of a family business was referred to as the most powerful wealth driver in their countries. Contrary to that, inheritance does not seem to be regarded as a decisive wealth factor in the opinion of students from transforming or post-socialist economies. It was mentioned sporadically in Polish students' essays and has not appeared at all in essays from Russia and Ukraine.

\subsection{Income from private business}

Private business ownership is perceived as a strong wealth contributor by students from all countries. While most students simply indicated private entrepreneurship as an important wealth driver without further elaboration, there were some country-specific examples of most profitable business areas and the way the business should be launched. 
Table 2. Country-specific opinions concerning "income from private business"

\begin{tabular}{|l|l|}
\hline \multicolumn{1}{|c|}{ Country } & \multicolumn{1}{c|}{ Students' original quotations } \\
\hline Austria & $\begin{array}{l}\text { Be an entrepreneur in construction sector, real estate, or finance. } \\
\text { Own a business in combination with foreign countries. } \\
\text { Find a market niche, work hard to build up an international company. }\end{array}$ \\
\hline The Netherlands & $\begin{array}{l}\text { Create innovative solutions. } \\
\text { Bring innovative spirit in engineering, shipping industry. }\end{array}$ \\
\hline Sweden & $\begin{array}{l}\text { Be an entrepreneur in the Internet business, e.g. gaming industry. } \\
\text { Set up a company and sell it. }\end{array}$ \\
\hline Poland & $\begin{array}{l}\text { Start a private business using the knowledge gained in state companies. } \\
\text { Import goods that are lacking on the domestic market. } \\
\text { Set up own business with the use of European funds. } \\
\text { Have access to EU funds for entrepreneurs. } \\
\text { Set up own business as a shield to taxes. }\end{array}$ \\
\hline Russia & $\begin{array}{l}\text { Import or smuggle goods to Russia. } \\
\text { Operate on a black market. } \\
\text { Adapt ideas which are successful abroad and develop them in Russia. }\end{array}$ \\
\hline
\end{tabular}

Source: Own elaboration.

\subsection{Income from financial investments}

This factor was recognized as important by nearly all participants, with the exception of students from Russia and Ukraine. While other students referred directly to stock exchange or to specific financial instruments (stocks, bonds), there was only a vague mention of Russian stock exchange in one or two essays from Russia and no mention at all in essays of Ukrainian students. What is interesting, students from Poland were the only ones who underlined the necessity of having basic financial knowledge and know-how in the field of financial instruments and investments before engaging in stock exchange trading.

\subsection{Income from real estate}

This way of obtaining income and accumulating wealth was particularly strongly emphasized in essays written by Austrian, German, and Swedish students. In many cases they pointed to property trading and rental income as a way of securing a retirement provision. Specific examples were found in Austrian essays, like: "Investing in real estate in megacities in Austria and Germany" or "Investing in property market supported by tourism industry". Like in the case of financial income, income from real estate does not seem to be regarded as a key wealth driver by students from transforming economies. It was mentioned sporadically in Polish, Russian, or Ukrainian essays and lacked any particular exemplifications. 


\subsection{Income from employment and self-employment}

The analysis of this factor revealed significant differences on how students position labour income in the order of priority among different sources of wealth. Whereas students from well-established economies and from Poland seem to understand the falling importance of labour income in wealth accumulation process, students from Russia and Ukraine accentuated income from employment as the primary and safe way of building private wealth. Western students pointed to tax issues connected with employment or expressed their generally sceptical views on labour as a source of wealth. On the other hand, Russian students did not mention taxes at all, featuring stabile job positions in big, mostly state-owned companies as a good option for personal career.

Table 3. Country-specific opinions concerning "income from employment and self-employment"

\begin{tabular}{|l|l|}
\hline \multicolumn{1}{|c|}{ Country } & \multicolumn{1}{c|}{ Students' original quotations } \\
\hline Austria & $\begin{array}{l}\text { Because of progressive taxation system, it is not possible to get rich with } \\
\text { an employee income or savings. Big part of the pay is given to the state. } \\
\text { It is very hard to get rich in Austria just as a normal worker or an employee } \\
\text { in some company. }\end{array}$ \\
\hline Sweden & $\begin{array}{l}\text { Taxes make it difficult to become rich just by earning salary or doing a wage- } \\
\text { based work. } \\
\text { In Sweden it is hard to become very rich as an employee, even if you have } \\
\text { a great career. } \\
\text { Live in Sweden, work in Norway. }\end{array}$ \\
\hline The Netherlands & $\begin{array}{l}\text { It is not worthwhile to work harder. } \\
\text { It is difficult to make serious money while being employed. }\end{array}$ \\
\hline Poland & $\begin{array}{l}\text { Work in a traditional sector of Russian economy. } \\
\text { Work for extraction industry. } \\
\text { Have an executive position in a big state company. } \\
\text { Be a government officer. } \\
\text { Wealthy people do not work for other people. }\end{array}$ \\
\hline
\end{tabular}

Source: Own elaboration.

\subsection{Other non-specified sources of income}

In this broad category, many original propositions appeared covering a vast array of sources of income, both accidental and premeditated. Students mentioned such ways of making money as: winning the lottery, being an outstanding performer in sports, arts, or medicine, engaging in professional gambling (poker), using the Internet to do business, being innovative, create new solutions, being 
a programmer, web developer, or a famous blogger, using agricultural subsidies, engaging in tax avoidance, or marrying into a rich family - to mention only the most interesting examples.

In order to throw a light on some characteristic country-specific opinions, the original quotations from essays from Sweden, Poland, Russia, and Ukraine are presented below. They refer either to particular circumstances of making money on local markets or reveal critical observations concerning domestic dysfunctions of economic systems noticed by the students. What is symptomatic, the critical remarks appeared spontaneously in most Eastern students' papers, whereas they were not found in Western students' essays.

Table 4. Country-specific opinions and critical remarks on local market conditions

\begin{tabular}{|c|c|}
\hline Country & Students' original quotations \\
\hline Sweden & $\begin{array}{l}\text { General country-specific remarks: } \\
\text { High income tax and social security contribution result in generous welfare with } \\
\text { low inequality. } \\
\text { The richest people in Sweden are not the ones who made their fortune in traditio- } \\
\text { nal areas but the ones who were able to revolutionize that area of business. } \\
\text { You don't have to be rich in Sweden to have a good life. }\end{array}$ \\
\hline Poland & $\begin{array}{l}\text { General country-specific remarks: } \\
\text { Using the opportunities of transformation } \\
\text { Using EU grants } \\
\text { Combination of external factors with the ability of Poles to take chances, work } \\
\text { hard, take risks. } \\
\text { Critical observations: } \\
\text { Declining role of education as wealth driver. } \\
\text { Workaholism, too much time devoted to work. } \\
\text { Illegal ways of making money like financial pyramids, mafia, corruption. }\end{array}$ \\
\hline Russia & $\begin{array}{l}\text { General country-specific remarks: } \\
\text { Getting education in Europe, understanding European way of earning money. } \\
\text { A lot of ideas that are used abroad can be brought to Russia as something new. } \\
\text { Know the right people, political connections. } \\
\text { Critical observations: } \\
\text { Connections with government. This sort of connections might put down your com- } \\
\text { petitors, reduce taxes or even oblige someone to use your business. } \\
\text { Privatization of state enterprises. No legislative framework after the collapse of the } \\
\text { USSR. } \\
\text { Worn infrastructure, overlapping and changing laws, bureaucracy. } \\
\text { Financial ignorance, no strong entrepreneurial spirit, little stock exchange activity. } \\
\text { Paid education and private universities lower the level of education, lead to the } \\
\text { emergence of "incompetent professionals". } \\
\text { Decreased population, alcoholism, drugs. }\end{array}$ \\
\hline
\end{tabular}




\begin{tabular}{|c|l|}
\hline Country & \multicolumn{1}{c|}{ Students' original quotations } \\
\hline \multirow{5}{*}{ Ukraine } & $\begin{array}{l}\text { General country-specific remarks: } \\
\text { Networking - the use of contacts to acquire information, advice and referrals. } \\
\text { Critical observations: } \\
\text { Buying and using media conglomerates, influencing government decisions. } \\
\text { Political connections, buying up state-owned enterprises. } \\
\text { Racketeering, bandit wars for assets, overwhelming corruption in government. } \\
\text { Over a period of 20 years these phenomena have become legitimized and have } \\
\text { grown into a social norm. }\end{array}$ \\
\hline
\end{tabular}

Source: Own elaboration.

\section{Conclusions}

This study reveals that there is a strong connection between personal experience and the understanding of economic processes determining private wealth accumulation. Factors which occur on particular markets and can be observed in students' everyday life are perceived as the strongest ones in their opinion. On the other hand, those wealth contributors which have not had the chance to develop because of specific economic conditions on emerging markets are not considered important, although the common knowledge proves the opposite. Of course, there is a limitation to this research, as its scope is fairly limited so its findings cannot be widely generalized. Nevertheless, the differences between the opinions of students from developed and transforming economies prove that a universal phenomenon of private wealth is perceived through the prism of subjective countryspecific experience.

Another interesting conclusion refers to the ability of students to notice market dysfunctions. Young people are not indifferent to the irregularities occurring on their domestic markets. Not only are they noticing them in their critical comments, but they are also capable of trying to formulate a diagnosis of their origins and consequences.

\section{References}

Braun V., Clarke V., 2006, Using thematic analysis in psychology, Qualitative Research in Psychology, vol. 3.

Consultancy.uk, 2017, Global private wealth to exceed \$200 trillion as the rich get richer, https:// www.consultancy.uk/news/13650/global-private-wealth-exceed-200-trillion-as-therich-get-richer [access: 20.01.2018].

Crossman A., 2016, An overview of qualitative research methods, https://www.thoughtco.com/ qualitative-research-methods-3026555 [access: 02.01.2018]. 
Fessler P., Schurz M., 2015, Private wealth across European countries: The role of income, inheritance and the welfare state, ECB Working Paper Series, no. 1847.

Galbraith K.J., 1958, The affluent society, The Gale Group, New York.

Hsieh H.-F., Shannon S.E., 2005, Three approaches to qualitative content analysis, Qualitative Health Research, vol. 15.

Kennickell A., 2008, Ponds and streams: Wealth and income in the U.S., 1989 to 2007, Finance and Economics Discussion Series, Federal Reserve Board, Washington, D.C.

Linklater A., 2013, Owning the Earth: The transforming history of land ownership, Bloomsbury, New York.

Maude D., 2006, Global private banking and wealth management, Wiley \& Sons, Chichester.

O'Driscoll G.P., Hoskins L., 2003, Property rights: The key to economic development, https:// www.libertarianism.org/publications/essays/property-rights-key-economic-development [access: 04.01.2018].

Philips K., 2003, Wealth and democracy: A political history of the American rich, Broadway Books, New York.

Piketty T., 2014, Capital in the twenty-first century, Belknap Press, London.

Smith N., 2015, Piketty's three big mistakes, Bloomberg, https://www.bloomberg.com/view/articles/2015-03-27/piketty-s-three-big-mistakes-in-inequality-analysis [access: 08.08.2018].

Tofler A., Tofler H., 2007, Revolutionary wealth: How it will be created and how it will change our lives, Knopf, New York.

J. Pietrzak (®) jo.pietrzak@gnu.univ.gda.pl

Wydział Ekonomiczny, Uniwersytet Gdański, ul. Armii Krajowej 119/121,

81-824 Sopot, Polska 